\title{
'N NARRATIEF-PASTORALE BETROKKENHEID BY ADOLESSENTE MEISIES WAT SEKSUEEL MISBRUIK IS ${ }^{1}$
}

\author{
Hester Fourie \\ Departement Praktiese Teologie \\ Universiteit van die Vrystaat \\ Jan Albert van den Berg \\ Departement Praktiese Teologie \\ Universiteit van die Vrystaat
}

\begin{abstract}
A Narrative Pastoral Involvement with Adolescent Girls who have experienced Sexual Abuse

The phenomenon of sexual abuse is a complicated matter that includes therapeutic as well as legal aspects and which is the result of the complex interaction between individual, social and environmental influences. The purpose of this research is to map the importance of hope therapy from an eschatological perspective in the healing process of adolescent girls who have experienced sexual abuse. This article focuses, in the first instance, on the understanding of the identity of a teenage girl from a theological anthropological perspective. Secondly, the focus shifts to what the phenomenon of sexual abuse entails, the impact of this form of abuse on how an individual understands her identity in Christ, as well as a narrative pastoral involvement with female adolescents who have experienced sexual abuse. Thirdly, the importance of a perspective of Christian hope, born from faith in God, as space and place for the praxis of God's committed involvement in the life-story and suffering of adolescent girls who have experienced sexual abuse, is highlighted. This research is portrayed by the metaphor of cartography and the mapping of the research journey occurs according to the five directives of the ABDCE approach to narrative research as developed and used by Julian Müller and others.
\end{abstract}

\section{Sleutelwoorde:}

\section{Inleiding en aktualiteit}

Ek was die afgelope agt jaar as pastorale terapeut by verskillende skole in Kroonstad en omgewing betrokke. 'n Beduidende aantal van die adolessente meisies by wie ek gedurende hierdie tyd in pastorale gesprek betrokke was, is op die een of ander ouderdom seksueel misbruik. My waarneming op grond van hierdie gesprekke sluit aan by dié van Wickham en West (2002:4), naamlik dat, "Child victims of sexuality, beyond their emotional and physical developmental levels, are violated in every sense of the word: physically, psychologically, emotionally and spiritually."

Hierdie artikel is gebaseer op dr Hester Fourie se doktorale proefskrif met die titel: "'n Narratief-pastorale betrokkenheid by adolessente dogters wat seksueel misbruik is". 
Ek het daarom navorsing begin doen oor die fenomeen van misbruik en het gevind dat die navorsingsterrein van seksuele molestering en die impak daarvan op slagoffers al telkemale onder die loep geneem is (Moore 1985; Richardson \& Bacon 2001; Spies et al. 2006; Coetzer 2009). Ek het egter gevind dat die negatiewe impak van molestering op die spirituele vorming van die adolessent selde as die fokus van navorsing dien. As bykomende bydrae tot dié navorsing word die negatiewe impak van molestering op die spirituele vorming van die adolessent as fokus geneem. Die invloed van molestering op die spirituele ervaring van die slagoffer is 'n werklikheid en word soos volg deur die persoon wat misbruik ervaar het, maar dit sinvol kon verwerk, beskryf: "You feel rejected, unloved, worthless, disconnected from and abandoned by your Creator" (Crisp 2007:301).

Vanuit my eie betrokkenheid as terapeut binne die aangeduide konteks, is die impak van molestering op die spirituele ervaring ${ }^{2}$ van slagoffers onder meer soos volg deur gespreksgenote $^{3}$ wat aan die navorsing deelgeneem het, verwoord:

- Jeanine: Ek is te kwaad vir Hom om te wil lewe. Hy het my verraai want Hy het dit nie gekeer nie. Ek kon hom nie keer nie, want ek was te klein.

- Zoe: Ek weet die Here is daar, ek weet net nie of Hy vir mý daar is nie. Al my gebede dat dit moet ophou het nie gehelp nie. Hy het my nie gehoor nie. Ek kan nie meer bid nie, want my gebed slaan teen die dak vas.

- Karla: God sou dit gekeer het as Hy vir my omgegee het. Ek is in elk geval tweedehands en hoort op die ashoop. Hy gee seker net vir die heiliges om.

Bovermelde fragmente uit die verhale van gespreksgenote wat misbruik ervaar het, dui aan dat daar by hierdie individue, as gevolg van wat met hulle gebeur het, 'n negatiewe spiritualiteit ten opsigte van wat hulle van God verstaan, ontstaan het. Dit kan moontlik 'n negatiewe toekomstige oriëntasie van wanhoop in stede van hoop daarstel.

In die titel word aangedui dat die navorsing 'n narratief-pastorale betrokkenheid by adolessente meisies wat gemolesteer is, veronderstel. Volgens Ganzevoort (2007:100) word daar in die narratiewe benadering ${ }^{4}$ gepoog om te verduidelik en te beskryf wat in die pastorale ontmoeting plaasvind. Die gespreksgenote wat by hierdie navorsing betrokke was, is in hierdie ontmoeting as medenavorsers betrek, wat weer dui op 'n bepaalde betrokkenheid by individue wat deelneem aan die navorsingsproses (De Beer \& Van den Berg 2011:143). Slegs fragmente uit die drie meisies - wat as medenavorsers by die studie betrokke was - se verhale word in die kartering van ' $n$ navorsingsreis gebruik weens sensitiwiteit vir empiriese ontledings van en/of verkeerdelik veralgemenende afleidings. Dié fragmente tesame met verhelderende perspektiewe uit die gangbare literatuur en die Bybel, word vervolgens op prakties-teologiese wyse in 'n sirkulêre- en spirale beweging ${ }^{5}$ tussen praktyk en teorie aangebied.

2 "In one way or another, spirituality is related to faith and the experiences of faith, while God-images also come into play" (Louw 2008:49).

3 Skuilname is in alle gevalle gebruik. Waar medenavorsers aangehaal word, word hulle skuilname onderstreep en word die teks in ingekeepte formaat aangebied.

$4 \quad$ Die keuse vir die narratiewe benadering vind aansluiting by die pastoraat "als zorg voor het verhaal van mensen in relatie tot het verhaal van God. In het pastoraat staat dus het levensverhaal van mensen én het verhaal van God centraal" (Ganzevoort \& Visser 2007:100).

5 "Practical theological interpretation often circles back like a spiral as insights emerge" (Osmer 2008:11). 


\section{Kartografie as toegangsmedium tot die onbekende: 'n fokus en metodologiese uitgangspunt}

In die dokumentering van 'n narratief-pastorale betrokkenheid by adolessente meisies wat misbruik ervaar het, word kartografie as metafoor gebruik om die verloop van die navorsing te beskryf. Wanneer kartografie ter sprake kom, tree die aspekte van ruimte en plek terselfdertyd na vore. In metaforiese sin kan ruimte verwys na die intellektuele en spirituele vermoë om te verstaan.

Teen hierdie agtergrond het ek die volgende navorsingsvrae as merkers gebruik ten einde die ondersoek te fasiliteer: Hoe kan 'n adolessente meisie verstaan word in die lig van 'n teologiese antropologie? Watter impak het misbruik op 'n vroulike adolessente slagoffer se identiteit in Christus? Wat behels 'n narratiewe pastorale betrokkenheid by my gespreksgenote in die lig van Christelike hoop soos gesetel in geloof in God?

Die roete waarlangs die navorsing gekarteer word, word aangedui deur sekere koördinate. Die verskillende koördinate word gekarteer na aanleiding van die ABDCEnavorsingsbenadering ${ }^{6}$ soos ontwikkel deur Müller, Van Deventer en Human in hulle artikel, 'Fiction writing as metaphor for research: A narrative approach' (2001). Die akroniem ABDCE staan vir Action, Background, Development, Climax en Ending en dien as perspektiewe ter interpretering van 'n narratiewe werklikheid.

\section{'Action' as Koördinaat 1}

Aksie word geneem ten opsigte van wat 'nou' besig is om te gebeur (Müller, Van Deventer \& Human 2001:2). Die 'nou' in die navorsingsproses maak gebruik van die metafoor van spoorsny om op die navorsingsweg te bly. In dié navorsingsreis dien die verhale van die medenavorsers as landskap van aksie vir hierdie studie. Getrou aan die navorsingsoriëntasie word van die insigte gebruik gemaak van drie medenavorsers, wat na hulle goedkeuring van die dokumentering en bekendstelling van fragmente uit hulle verhale, vervolgens aan die leser bekend gestel word:

- Jeanine is deur haar ma se broer gemolesteer toe sy agt jaar oud was. Haar ma wou haar nie glo toe sy dit openbaar gemaak het nie. Sy is nou 17 jaar oud, en haar ma weier steeds om daaroor te praat. Jeanine sien haarself as iemand wat, weens die feit dat God nie die misbruik gekeer het nie, buite die genadekring van God val.

- Zoe is in pleegsorg by haar grootouers geplaas nadat haar ma op 15-jarige ouderdom met haar swanger geraak het. Zoe is deur haar oupa misbruik vandat sy agt jaar oud was. Haar ouma het aangedring om te weet waaroor Zoe se onbedaarlike huilbuie gaan toe sy 12 jaar oud was, en sy moes haar vertel. Haar grootouers is daarna geskei, en Zoe moes by haar ma en stiefpa gaan woon. Sy het telkemale gebid dat God haar oupa moet stop. Weens die feit dat hy slegs 'n opgeskorte vonnis gekry het en dat Hy nie die molestering gekeer het nie, het sy die afleiding gemaak dat God haar oupa bevoordeel bo haar.

- Karla weet nie wie haar pa is nie, aangesien hy haar ma verlaat het toe sy swanger was. Karla is etlike kere op verskillende ouderdomme deur haar ma se manlike kuiergaste gemolesteer, waarop sy in 'n kinderhuis geplaas is. In die lig van haar

6 Die ABDCE-navorsingsmodel model is ontwikkel om uitdrukking te gee aan die moontlikheid van 'n narratiewe navorsingsmodel. Elk van die aangeduide bewegings in die betrokke navorsingsmodel verteenwoordig 'n narratiewe karakter. 
persepsie dat God haar nie wou help nie, voel Karla dat God haar nie as waardevol genoeg geag het om haar te beskerm nie.

In die narratiewe benadering word die landskap van aksie saamgestel uit menslike gebeure wat aaneengeskakel is in spesifieke orde deur bepaalde tydsdimensies en wat volgens 'n spesifieke storielyn ontwikkel (White 1992:125). In die verhale van die medenavorsers het molestering gedreig om die destruktiewe hoofkarakter in medenavorsers se verhale te word. Uit gemelde verhale van misbruik en kondisionering is dit onder meer duidelik dat gespreksgenote God verkwalik dat Hy as liefdevolle en Almagtige nie die molestering gekeer het nie (Wickham \& West 2002:166).

Ten einde die aard van molestering te begryp, moet egter gelet word op wat die aksie van molestering behels:

Any sexual contact between an adult (socially and physically defined) and a sexually immature child for the purposes of the adult's sexual gratification; or deceit to secure the child's participation; or sexual contact to which the child is incapable of consenting by virtue of age or power differentials and the nature of the relationship with the adult (Guma \& Henda 2004:99).

Die spektrum van misbruik dek 'n wye reeks seksuele dade teenoor kinders, wat strek van marteling, slae, verbale en psigologiese mishandeling, ekshibisionisme, pornografie, bloedskande en kondisionering vir misbruik deur middel van die internet (McGregor 2008:17). Volgens Spies (2006:45-51) volg seksuele misbruik dikwels 'n tipiese fase-orde, soos vervolgens aangedui sal word.

'n Moontlike slagoffer word gekondisioneer vir molestering deurdat sy voorgetrek word en fisiese kontak vind op 'n oënskynlike gepaste wyse plaas, sodat sy geleidelik gewoond kan raak aan die aanraking van die oortreder. Dit word dan later gevolg deur fisiese kontak wat net ietwat verder as die aanvaarbare grense gaan. Die fisiese molestering kan wissel van betasting tot penetrasie. Wanneer 'n slagoffer toenadering weier, reageer die oortreder dikwels met 'n onskuldige nie-eisende liefde jeens haar. Dit word gesien as 'n wyse van beloning of omkoop ter voorbereiding van die volgende ontmoeting. Wanneer die intensiteit van die dade toeneem, word die stilswye van die slagoffer verseker deur fisiese dreigemente wat verband hou met liggaamlike leed wat gemik is op die slagoffer self, of iemand na aan haar. Psigologiese dreigemente is ewe kragtig. Ter wille van die voortsetting van molestering, sal die oortreder sy mag gebruik om die slagoffer te domineer, om te koop, te dreig of af te pers. Dit het duidelik uit die volgende spesifieke opmerkings in medenavorsers se verhale geblyk:

- Jeanine: My oom het my altyd spesiaal aandag aan my gegee, daarom was ek baie lief vir hom. Na die gebeurtenis het my oom gesê hy sal dit net ontken as ek vir my ma sê.

- Zoe: Ek was baie lief vir lekkerruikseep en sjokolade en my oupa het dit altyd vir my gekoop. Hy het gesê dit is omdat ek so soet is en ek mag nie vir my niggies wys nie, want hulle is stout. Ek was te bang om vir my ouma te sê toe hy my gemolesteer het, want hy het gesê hy sal tronk toe gaan en dan is daar niemand om vir ons te sorg nie.

- Karla: Die ooms wat by my ma gekuier het, of wat van tyd tot tyd saam met haar gebly het, was altyd spesiaal vriendelik met my en het speelgoed aangedra. As ek gedreig het om vir die juffrou te gaan sê, het hulle gesê niemand sal my glo nie, en my ma sal nie sonder die geld wat hulle haar gee, kan oorleef nie. 


\section{'Background' as Koördinaat 2}

Die sogenaamde Background-moment verwys na die verlede sowel as die hede van die landskap wat die agtergrond tot die interpretering en betekenis van hierdie navorsing vorm (Müller, Van Deventer en Human 2001:2). Ter verdere uitdrukking van die pastorale karakter van die navorsing, dien 'n teologies antropologiese verkenning van die adolessente meisie wat misbruik ervaar het, vervolgens as tweede koördinaat tot oriëntering.

\section{'n Teologiese antropologie}

Hoewel die term 'identiteit' nooit per se in die Bybel voorkom nie, gee die Skrif aan die mens sy/haar identiteit deur aan te dui hoe hy/sy in die verhaal van God inpas en hoe daardie identiteit uitgeleef behoort te word (Snodgrass 2011:4). In die gemoed van my gespreksgenote - soos in die aangehaalde fragmente van hulle verhale aangetref - ontstaan die volgende vrae: "Wat beteken dit alles vir my?" en "Wat beteken God in dit alles?" Die 'hoekom'-vraag wat deur hulle gevra word, vra na God as Skepper en onderhouer van alles wat bestaan, en wat ook in die mens binne die Skepping teenwoordig is.

Sentraal tot die Bybelse verstaan van die mens in Skrifgedeeltes soos Gen. 1:26; 9:6; 2:23-24; Ps. 8 en Ps. 139, is die oortuiging dat man en vrou geskape is na die beeld van God (Imago Dei). Hierdie beeld fokus op die uniekheid van die mens wat van God afhanklik is en dat die uiteindelike bestemming van die mens uit daardie verhouding tot God geïnterpreteer word (Ps. 139; Louw 1999:182). Die beeld van God word voorts in die mens as unieke beliggaamde menslike wese gevind waarbinne liggaam, siel, verstand en wil vervleg is (Louw 1999:196). Tydens die pastorale ontmoetings moet in gedagte gehou word dat die unieke bydrae van die teologiese antropologie juis daarin lê dat dit nie negatief oor my gespreksgenoot wil reflekteer nie, maar eerder op wat die persoon se wesenlike gerigtheid, oorsprong en eindbestemming is (Louw 1999:181).

Dit beteken dat sy beskik oor 'n verlede, hede en toekoms. Die narratief-pastorale teologie stel dus in my gespreksgenote belang as wesens met 'n verhaal wat oor tyd gekoppel is aan hulle Godgerigtheid, sondigheid, verlossing en geloof (Schmutzer 2008:792). Hierdie verhaal sluit ook hulle geleefde ervaring van verskillende gebeure op verskillende tye van hulle lewe in. Vir my gespreksgenote is dit baie moeilik om hulle onderskeie verhale van adolessente ontwikkeling, asook hulle ervaring van misbruik, in verband te bring met God se verhaal en Sy ware aard. Die rede is dat hulle selfwaardering as geskapenes na die beeld van God aangetas is deur die geleefde ervaring van molestering. Nadat Ps. 8 en Ps. 139 onder meer saam met my gespreksgenote as deel van die narratiewe pastoraal terapeutiese proses en as deel van 'n wederkerige gesprek behandel is, was hulle onderskeie reaksies soos volg:

- Zoe: Ek hoor wat die Bybel sê, maar ek kan nie daardie prentjie en die prentjie van my lewe bymekaar bring nie.

- Jeanine: As dit van my en my lewe waar was, waarkom kry ek met soveel geweld te doen?

- Karla: Dit voel of die Bybel van iemand anders praat. Hoe pas dit in by al die dinge wat al aan my gedoen is?

Die betekenis van die konteks van misbruik dui dus daarop dat die woorde van God gehoor moet word in die kompleksiteit van die lewe self. Dié uitdaging om die betekenis en relevansie van God se woorde vir gespreksgenote oor te vertaal, word selfs groter deur die 
kompleksiteit wat seksuele misbruik toevoeg tot die ontwikkelende identiteit van die adolessent.

\section{Die samehang tussen 'n teologiese antropologie en misbruik}

Trauma $^{7}$ kan beskryf word as 'n verwonding op 'n verskeidenheid van vlakke wat ontstaan weens 'n ernstige gebeurtenis en wat die slagoffer se integriteit versplinter met gevoelens van magteloosheid en vervreemding (Ganzevoort 2001:20). Trauma is egter nie die gebeure as sodanig nie, maar die impak wat dit op die identiteit van die slagoffer het. Die trauma van misbruik hou daarom verband met die inhoud, erns, duur en konteks van die gebeure. Die impak van molestering hou ook verband met my gespreksgenote se unieke persoonlikhede en hanteringsvaardighede, hulle ervaring van sin en betekenis, en op die wyse waarop adolessente ontwikkelingstake hanteer word, asook die aard van ondersteuningsbronne (Crisp 2007:302).

Misbruik het verwoesting tot gevolg omdat dit die werklikhede van wat dit beteken om mens te wees vernietig, gedelegeerde gesag word destruktief, seksuele uitdrukking word verdraai, inter-persoonlike vertroue word vernietig en die diepgaande metafore vir God word vermink (Schmutzer 2008:786). Wanneer die outentisiteit van die ander persoon as beeld van God na wie omgesien moet word nie gerespekteer word nie, word die liefde van God weerspreek (Ef. 5:21-33).

Misbruik sny dus die band tussen die 'wie' van menswees en die 'wat' van beliggaamde lewe omdat die gebeure deur die vervlegte eenheid van liggaam, siel en verstand onthou word. Die gawe wat God aan die mens gee, naamlik sy Gees en verskeie kenmerke van die menslike ervaring wat die stempel van God se beeld van die mens dra, naamlik persoonlikheid, spiritualiteit, rasionaliteit, moraliteit, gesag en kreatiwiteit word hierdeur aangetas. Molestering is daarom 'n vergryp teen God wat in die geval van my gespreksgenote gelei het tot versteurde geloofsoriëntasies hoofsaaklik weens skeefgetrekte Godskonsepte. Uit die volgende opmerkings van my gespreksgenote is dit duidelik dat hulle aan God 'n naam gee, in plaas daarvan dat God aan hulle 'n naam gee, wat lei tot skeefgetrekte perspektiewe oor God.

- Zoe: Ek het al detensie gesit omdat ek pouse gerook het. Wat die onderwysers nie kan verstaan nie, is dat dit al is wat my help om te kalmeer wanneer dit voel of ek my selfbeheer gaan verloor. Ek het vir God gevra hy moet my rooklus wegvat, maar dit gebeur nie.

Sy sien dus haar geloof as versekering teen lyding en God as versekeringspolis. Omdat God nie intree soos wat sy verlang nie, ervaar sy onbetrokkendheid. Dit lei tot 'n verknegtingsperspektief aangesien daar voortdurend gewag word dat God op elke behoefte moet reageer (Perrin 2005:454).

- Jeanine: Ek weet nie waaroor die bohaai gaan nie. Ek het net 'n paar pynpille gedrink om te kan cope en toe lag en huil ek deurmekaar. Ek moet dit partykeer doen, want niemand anders is daar vir my nie. As ek dit net kan regkry om my ma

Ganzevoort wys daarop dat trauma onder meer 'n verlies aan 'n begrip van die wêreld, verhoudings met ander en die self impliseer: "These three fundamental assumptions are challenged in traumatization. We lose our place in the world. We lose our connection to others. We lose our sense of self ... this connection of trauma and identity is closely related to central theological issues. The basic assumptions are not only psychological mechanisms that sustain our identity and our being in the world. They are also the foundations for a religious identity and being in the world spiritually" (Ganzevoort 2008:26). 
en my oom te vergewe, maar ek was 'n onskuldige dogtertjie, hoekom het God dit nie gekeer nie?

Jeanine beskou God as onregverdig omdat die gebeure nie gekeer is nie. Wanneer vergifnis dan ter sprake kom, ervaar sy dit opnuut as misbruik. Die resultaat hiervan is wanhoop, magteloosheid, eensaamheid, woede, weerstand, skuld en vertwyfeling.

- Karla: Daardie spul heiliges in my klas kap my omdat ek rook en omdat ek saam met ouens slaap. Hulle verstaan nie dat ek nie worry nie, want God het dit nie gekeer nie, en ek het stilgebly oor die gelollery met my. Partykeer dink ek Hy straf my, want niks in my lewe loop reg nie.

Karla beskou die molestering wat sy beleef het as straf omdat sy 'n onderskeid tref tussen haar en ander wat nie misbruik is nie (heiliges). Skuld ontstaan uit haar aanname dat sy iets verkeerd gedoen het. Daar word algemeen aanvaar dat God dié wat lewe en dié wat reeds dood is, oordeel. Lyding word dan met oordeel gelyk gestel.

Geloof in God dui nie slegs op bepaalde opvattinge oor God nie, maar dit beteken ook dat die mens in 'n dinamiese verhouding tot God lewe. God mag egter nie gereduseer word tot alleenlik 'n lewensantwoord vir menslike lyding nie, aangesien Hy dan nie meer God is nie (Müller 2000:64). Hieruit is dit duidelik dat herstrukturering van ontoepaslike Godskonsepte belangrik is vir spirituele heling en dat Skrifgebruik verantwoordelik toegepas moet word op weg na 'n verantwoordelike beskouing van God. Christelike spiritualiteit word in hierdie verband gesien as 'n “...openness to the guidance of the Holy Spirit as she forms and transforms them toward the image of Christ in his body and in the service of the church's mission" (Osmer 2008:27). Hoop word geïnterpreteer as dimensie van tyd deurdat dit aktief geskied in die verlede, hede en toekoms. Hoop word versterk uit die toekoms, maar motiveer die mens ook om te lewe sodat God "...se wil op aarde kan geskied, soos in die hemel" (Matt 6:10). Die transendente faktor dui hier op die teenwoordigheid van God en die ervaring om menswaardig in die teenwoordigheid van God te leef.

\section{'Development' as Koördinaat 3}

Die derde beweging van die voorgestelde narratiewe navorsingsproses van die karteringsproses kan vergelyk word met die ontwikkeling van ' $\mathrm{n}$ foto van die navorsingslandskap (Müller, Van Deventer en Human 2001:3). Twee vrae wat hier deur die praktiese teoloog gevra word, is: Wat is besig om te gebeur? Hoe verstaan ek hierdie konkrete situasie waarin in diens van God opgetree moet word? Dié vrae vind weer aansluiting by 'n prakties-teologiese hermeneutiek wat te make het met die interpretasie van menslike handelinge binne sosiale kontekste (Louw 1997:56).

In Bybelse terme word die verhaal van die mensdom gedra deur die verbond as intieme interverwantskap tussen God en sy mense (Williams 2010:22). Wat in die Bybel as "God se Woord” gevind word, kan dus "...op geen manier losgemaak word van die behoeftes, omstandighede en eise van die wêreld waarin ons lesers hier en nou leef nie" (Van Niekerk 2005:35). Praktiese teologie vind hierby aansluiting met - as oriëntasie -'n soeke om 'n verband te vind met “...the critical, theological explorations of situations" (Swinton \& Mowat 2006:vii).

Volgens Anderson (2001:37) is praktiese teologie in wese 'n hermeneutiese teologie. Hermeneutiek bied as deel van 'n praktiese teologie-oriëntasie 'n fokus op die konkretisering en toepassing van die heilsboodskap (Louw 1999:253). Hierdie toepassing kan volgens Osmer (2008:15) nie anders wees nie as relasioneel en kontekstueel. Metodologies 
beteken dit dat die sosiale konstruksionistiese perspektief, veral met die klem op 'n narratiewe oriëntasie, in staat moet wees om die prosesse betrokke by misbruik te interpreteer. 'n Prakties-teologiese interpretasie behels volgens Osmer (2008:10) vier sleuteltake wat as voorbeeld aan die hand van fragmente uit Zoe se verhaal, soos volg omskryf kan word:

- Die beskrywend-empiriese taak handel oor die vraag oor hoe die konkrete situasie waarin in diens van God opgetree moet word, verstaan moet word?

Zoe is in die pleegsorg van haar grootouers geplaas omdat haar ma nog in die skool was toe sy swanger geraak het. Aanvanklik is albei haar grootouers vir haar 'n bron van sekuriteit en liefde, totdat haar oupa haar begin molesteer. Volgens haar Godskonsep moes Hy haar beskerm het omdat sy nog so klein was. Sy is daarom vir God kwaad.

- Die interpreterende taak ondersoek die verstaan en interpretering van die betrokke gebeure.

Die betrokke gebeure in Zoe se lewe wat verstaan en geïnterpreteer moet word, bestaan uit die volgende aspekte: Zoe se plek in 'n familie wat ekonomies nie goed daaraan toe is nie; haar ma wat op skool swanger raak en hoe dit Zoe se selfbeeld raak wanneer sy in pleegsorg geplaas word omdat haar ma nie na haar kan omsien nie; die feit dat haar grootouers geskei is na die openbaarmaking van die gebeure en Zoe wel by haar ma moet gaan bly; die impak van die gebeure op haar insig van God, asook haar identiteit in Christus.

- Die normatiewe taak ondersoek die vraag wat in die betrokke konteks behoort te gebeur.

In die lig van die paradigma van hierdie studie behoort 'n narratief-pastorale benadering tot die terapeutiese versorging van Zoe oorweeg te word. Dié oriëntasie tot die praktyk van Zoe se lewe word in en deur die navorsing aangetoon.

- Die pragmatiese taak handel oor die vraag na watter aksies strategies geneem en geïmplementeer kan word.

Die aksies wat geneem kan word, is om saam met Zoe haar duistere verlede te dekonstrueer met voortspruitende herkonstruksie daarvan tot 'n toekomsverhaal van hoop. Saam met Zoe is dié ontwikkeling gefasiliteer aan die hand van die metafoor van 'n leeu wat haar bedreig. Insig is ontwikkel tot die begrip dat die leeu in die verlede ingehok word deur verskeie beskermingsmeganismes. Hierdie begrip het mettertyd gegroei totdat Zoe begin ervaar het dat die leeu nie weggeneem kan word nie, maar dat dit haar nie meer bedreig nie. Sodoende word saam met Zoe as sogenaamde medenavorser gewerk om 'n nuwe voorkeurverhaal te konstrueer.

Hierdie onderskeie vier take is ineen verweef. Probleme wat in die pragmatiese taak na vore tree, moet verder empiries nagevors word, terwyl teorieë wat aangewend word om sekere gebeure te interpreteer 'n normatiewe perspektief daarop reflekteer. Die interaksie en gemeenskaplike invloede van die vier take onderskei praktiese teologie van ander studievelde, omdat die sosiale wetenskappe byvoorbeeld nie normatiewe teologiese perspektiewe vir interpretasie ontwikkel nie. Hierdie vier take word daarom gesien as funksionerend in 'n hermeneutiese sirkel "... which portrays interpretation as composed of distinct interrelated moments" (Osmer 2008:10).

Wanneer ervaring ter sprake kom, gaan dit oor die ontdekkende religieuse en spirituele omgang met die werklikheid wat oor verskillende domeine van die daaglikse geleefde ervaring strek (Williams 2010:257). Die werklikheid van geleefde religie kan egter nie 
wetenskaplik benader word asof die mens kan bewys dat God bestaan as objek teenoor subjek nie. Daarom word 'n narratiewe prakties teologiese benadering gevolg en word geprobeer om hierdie geleefde ervaring "...wat verband hou met die verhale van die Christelike geloofsgemeenskap, teologies te verhelder en te vernuwe" (Müller 1996:5). Die objek van Christelike teorievorming is nie God nie, maar die mens se reaksie op God. Wat God doen, doen Hy vir, met en deur alle mense, ook adolessente (Nel 2000:13), wat my gespreksgenote insluit, en daarom word die praxis weer eens ook in die volgende faset van die narratiewe navorsingsproses benadruk.

\section{'Climax' as Koördinaat 4}

Müller, Van Deventer en Human (2001:3) beskryf die dinamika van dié betrokke navorsingsfase soos volg: "You move them along until everything comes together in the climax, after which things are different for the main characters." Pastorale sorg groei juis uit 'n gegewe menslike situasie "...with the greatest breadth and richness of perception possible and the accompanying ability to relate these perceptions to a coherent and comprehensive theological framework" (Gerkin 1986:12). Ten einde die inhoud en betekenis van dié navorsingsfase te beskryf, word van die volgende oriëntasie gebruik gemaak.

\section{Die narratiewe benadering tot terapie}

Die sentrale beginsel van narratiewe teorie is dat dit self gekonstrueer en vertel word deur interaksie met ander en dat taal binne hierdie konteks betekenis gee, sodat dit nie slegs 'n weergawe van gebeure bied nie (Gower et al. 2005:155). Narratiewe terapie is veral geskik om mense te voorsien van 'n ervaring waar hulle 'n stem kan gee aan hulle trauma, hulle interpretasies kan evalueer, hulle gevolgtrekkings oor hulle identiteit kan heroorweeg en hulle lewensverhale kan herskryf vanaf slagofferskap tot oorwinning en hoop (Duval \& Béres 2007:233). In 'n narratief-pastorale benadering word kennis van die lewe saamgestel uit die geleefde ervaring van mense waar die verhaal van God en die verhaal van mense mekaar ontmoet (Ganzevoort 2007:100). Pastorale sorg groei dus uit 'n gegewe menslike situasie waar nie slegs die ervaring van misbruik ter sprake is nie, maar ook die ervaring van die transendente, naamlik God. Hoop groei uit die terapeutiese situasie en word saam met die gespreksgenote geskep in die vertel van hulle verhale.

Vir my gespreksgenote is die 'waarheid' oor hulleself die aangeduide impak van misbruik op hulle selfwaardering en identiteit. 'n Dekonstruksie van hierdie dele van die geïnternaliseerde verhaal wat geglo word die 'waarheid' is, dien om dit te ontgin. Die gespreksgenoot word in die proses aangemoedig om haar verhaal te vertel en te hervertel volgens alternatiewe en gewenste verhale van selfidentiteit, en volgens voorkeur lewenswyses. Daar word van geen vraelyste of meetskale gebruik gemaak nie. Wanneer verhale vertel word, word met die geheue gewerk en nie met die onderbewuste of onbewuste nie (Müller 1996:71). Verder word van die veronderstelling uitgegaan dat die komplekse verhouding tussen trauma en geloof fundamenteel 'n persoonlike en hermeneutiese saak is wat slegs uit die eie narratief verstaan kan word.

Vervolgens en as deel van die klimaksgebeure van die narratiewe navorsingsproses word in 'n sirkulêre beweging tussen praktyk en teorie. 'n reis deur tyd na hoop volgens die narratief-pastorale benadering gekarteer. Die gespreksgenote vertel hulle verhale in vyf sirkulêre bewegings tussen die verlede, hede en toekoms. 


\section{Die begin: ' $n$ Doolhof van verhale}

Die gespreksgenoot het nie meer 'n sinvolle verhaal nie (Ganzevoort \& Visser 2007:188). Dit is die eerste taak van die pastor om hierby aansluiting te vind en toe te sien dat die noodverhaal so goed as moontlik verwoord word deur met respek en ontsag na die verskillende ontknopingspogings van die vasgedraaide verhaal uit te vra en te luister. Binne die bestek van hierdie artikel is dit onmoontlik om die totale pastorale reis weer te gee, daarom word gefokus op gespreksgenote se vrae oor God se rol in die voorkoms van hulle lyding.

Voorbeeld van vrae wat gebruik is ter dekonstruksie van medenavorsers se onderskeie verhale word vervolgens aangedui:

- Hoor ek reg - jy voel jy het skuld aan die gebeure en dat jy daarom voel God sal jou nie vergewe nie?

- Ek hoor dat jou geloof wipplank ry. Wanneer voel jy magteloos, bang en alleen?

- Kan jy onthou van 'n tyd in jou lewe toe jy nie so gevoel het nie?

- Wanneer jy praat oor God se rol in die gebeure loop die trane. Wil jy vir my die storie van die trane vertel?

- Vertel my meer van die leeus wat jou vaskeer?

- Wat dink jy het hy bedoel toe hy gesê het jy is maklik?

Dit is belangrik om te onthou dat lydendes en die medenavorsers nie teoloë is nie, maar dat dít nie hulle vrae ongeldig maak nie. Müller dui tereg aan dat alle Godsbeelde uiteindelik maar taalkonstrukte is wat die mens of help of belemmer in hulle pogings om God te verstaan. Dit is eerder belangrik dat “...ons nie aan slegs één begrip uitverkoop nie, maar oop ... wees vir die onuitspreeklike veelkantige misterie van God" (Müller 2010:elektroniese bron).

\section{Die begin van die begin: Die eerste deur na die toekoms}

Dit is nodig om die verhaal te hervertel sodat die deur na die toekoms op 'n skrefie oopgemaak word. Grafiese voorstellings is 'n nuttige strategie wanneer gebeure ontken word, of wanneer die persoon nie kans sien om - weens die pynlikheid van die verlede - daaroor te praat nie. Die sketse dien as hermeneutiese teorie wat die sosiale, simboliese en religieuse dimensies van die individu se lewe interpreteer. Ek maak spesifiek van die volgende fragmente gebruik omdat dit elke gespreksgenoot se verhaal vertel nog voordat die molestering plaasgevind het. Die doel daarvan is om haar te laat besef dat sy deel is van 'n familiestelsel en -geskiedenis wat reeds kon bydra tot moontlike misbruik.

- Zoe: Ek sien dat mishandeling deel is van ons familie, want my ma en my ouma het mans wat hulle mishandel. Nie een van ons weet juis veel van die Bybel of van God af nie. Waar begin ek?

- Jeanine: Dit kan wees dat my oupa se opvoeding gemaak het dat die gesin nie mag praat oor gebeure en gevoelens nie. My oupa praat oor God, maar net dat ons reg moet leef om in Sy goeie boeke te wees.

- Karla: Ek sien dat daar in my ma se gesin baie geweld was. Sy en haar suster is vroeg uit die skool uit en het maar baie rondgeval omdat hulle nooit lank in een werk gebly het nie. Nie een van ons verstaan wat dit beteken om lojaal en getrou te wees aan iemand nie. Hoe sal ons verstaan dat God so is?

Grafiese voorstellings dien dus as dekonstruksie van die gespreksgenote se dominante verhale en bied die geleentheid om die historiese alternatiewe verhale te begin vertel. Dit is 
belangrik om in gedagte te hou dat elke mens uit sy/haar konteks die Bybel en God anders lees en verstaan.

Met hierdie agtergrond kan verstaan word dat die toekomsverhaal nie eksplisiet funksioneer nie, maar implisiet deurdat dit soos 'n embrio in die baarmoeder van die verlede lê (Müller 1996:87). Die embrio kan eers ontwikkel wanneer die rou materiaal van die toekomsverhaal uit die rommel van die verlede uitgesnuffel word. In die hermeneutiese sirkel word dieselfde elemente oor en oor hanteer, maar op verskillende vlakke. Vervolgens word die elemente van skuld, skaamte en die belang van die Evangelie in al drie die gespreksgenote se verhale getoon.

- Zoe: Tannie, ek sukkel nog om myself te vergewe omdat ek nie hard geskree of weggehardloop het nie. Al wat my hoop gee is dat Jesus reeds vir my sonde aan die kruis gesterf het.

- Karla: Hy weet hoe ek voel, want Jesus het as 'n mens aan die kruis gehang.

- Jeanine: Die enigste plek waar ek goed voel oor myself is wanneer ek by klein kindertjies is. Hulle kyk nie snaaks na my nie en aanvaar my sonder om vrae te vra. Ek het al begin dink dit is my gawe wat ek in diens van die Evangelie kan gebruik, en dit maak dat ek begin dink ek het dalk 'n toekoms.

Dit is belangrik dat die pastorale identiteit in die narratiewe beelde en metafore van die Christelike storie gewortel is. Hoop word omskryf as "...die toestand van bestaan waarin, deur die geloof, peil getrek word op God se vervulde beloftes en trou" (Louw 1999:426). Wat die verhaal van die verlede betref, “...[moet] daar... genoeg van die verlede-verhaal wees wat voortgesit kan word, maar daar moet ook genoeg wees wat nuut is sodat dit 'n krag tot nuwe homeostase kan wees" (Müller 1996:116).

\section{Terug by die begin}

Laag-op-laag gesprekke bied aan die gespreksgenoot die geleentheid om van die bekende wanhoop inherent tot die dominante storie te beweeg tot die ontdekking van hoop in die ontluikende alternatiewe verhaal (Duval \& Béres 2007:235). Voorbeelde van hoe medenavorsers dié momente van hoop in hulle eie verhale ontdek het word weerspieël in die volgende fragmente vanuit hulle vertellings:

- Zoe: Partykeer laat die herinneringe my baie af voel, dan dink ek daaraan dat Hy nie net gesterf het aan die kruis nie, maar dat Hy weer opgestaan het.

- Karla: My gemoed ry soms wipplank. Partykeer dink ek steeds ek is te sleg dat God my kan vergewe. Ander kere onthou ek weer dat Sy genade vir my genoeg is.

- Jeanine: Vandat ek geleer het dat God se liefde alles hoop, glo en verdra, het ek begin dink dat ek eerder so oor my ma en my oom moet begin voel.

Soos wat die gespreksgenoot die verlede bevry van die greep van die dominante stories, is sy in staat om ' $n$ minder problematiese toekoms te verbeel, te voorsien en te beplan. Die ontdekkingsreis na die toekoms word dus telkens gekarteer vanuit die verlede. Die gelowige word geleer om “...met die perikoop van geloof om die hoek van die dood te kyk” (Louw 1999:536). Die realisme van hoop bring egter nie vir alle probleme 'n oplossing nie, maar die sentrale storielyn kan ruimte gee, verbreed, verskuif en verander word.

Dit is hier dat 'n verband met die verhaal van God getrek moet word. Die pastor is as 'n verteenwoordiger van die Christelike tradisie 'n simboliese draer van die storie van God. 
Die Bybel is die wyse wat God gebruik om Homself op 'n narratiewe manier aan die mens te openbaar.

\section{Om 'n toekoms positief te onthou}

Snodgrass (2011:13) beskryf identiteit as die innerlike self-interpreterende geheue "...that includes some sense of the future ... for from our identity we project a future". Die geskiedenis van die mens word verby sy/haar geskiedenis opgeroep om in Christus te lewe. 'n Eerlike worsteling met God is deel van die geloofspad. Stemme uit die Bybel antwoord nie noodwendig die vrae van die gespreksgenoot nie, maar bied wel 'n perspektief daarop. Die ontdekking van vaardighede en dit waaraan sy waarde heg as die generering van hoopvolle uithouvermoë behels "...to perceive the possible in the actual, seeing possibilities immediately connected with the person" (Waaijman 2002:513). Hierdie hoopvolle oriëntasies het te doen met moontlikhede in die persoon se werklike lewensituasie. Die spesiale klem uit die volgende fragmente van medenavorsers illustreer 'n hoopvolle oriëntasie vir die toekoms:

- Zoe: Ek besef dat 'n mens nie teen die dak vas bid nie. God is altyd hier by my teenwoordig en ek kan Hom aanroep in my swaarkry. Dit is wat my tot dusver gehelp het om te oorleef. Ek kan na myself in die spieël kyk en sê dat daar vir my 'n positiewe toekoms is.

- Karla: Ek besef dat dit die Heilige Gees is wat my bewus gemaak het van God se genade. Jesus stuur wonderlike mense op my pad, ek het dit net nie vantevore raakgesien nie. Ek besef dat God in my deurmekaar lewe teenwoordig is en dat ek Hom daar kan aanbid.

- Jeanine: Jesus is steeds lief vir my, al is ek gemolesteer. Die 'slegte ek' oorheers nie meer my lewe nie. Ek is nog bang om Hom te vertrou, maar dit gaan al baie beter. Die molestering het gemaak dat ek meer vrae oor God begin vra het, wat my al nader aan Hom gebring het.

Binne die konteks van teologiese refleksie dui hoop op die mens se poging om die teenwoordigheid en wil van God op so 'n wyse uit te druk dat betekenis in die lewe ontdek word. Hierdie poging van die mens behels beide 'n hermeneutiese en kommunikatiewe onderneming waar die kommunikatiewe praxis van geloof vertaal word in die eksistensiële en lewenskategorieë van plek en ruimte (Louw 1999:107).

\section{Die 'ending', maar ook steeds pastoraat en route....}

Hierdie fase van die karteringsreis behels die volgende: "And then there is the ending: what is our sense of who these people are now, what are they left with, what happened, and what did it mean?" (Müller, Van Deventer \& Human 2001:8). Die karteringsreis van hierdie navorsing het geskied teen die agtergrond van 'n narratief-pastorale betrokkenheid by adolessente dogters wat seksueel misbruik is. Die narratief-pastorale benadering van hierdie navorsing word verantwoord in die sirkulêre funksionering van die empiriese, interpreterende, normatiewe en pragmatiese take van die praktiese teologie. Dit vind neerslag in 'n eie narratief-pastorale benadering ten opsigte van die betrokkenheid by adolessente meisies wat gemolesteer is.

Die vrae: "Wie is ek?" en "Wie is God?" wat deur die medenavorsers gevra is, het die fokus van die navorsing geplaas in die belang van geloofsorg binne die konteks van lewenssorg. In dié navorsing is bevestig dat 'n pastorale bediening bystandshulp aan mense 
is (Louw 1999:17). Die begrip 'terapie' het juis te doen met die funksies van heling, herstel en sensitiewe sorg wat konstruktiewe en positiewe implikasies vir die menslike bestaan en sinvolle funksionering kan hê (Louw 1999:510-511). Juis dié klem was belangrik in die fasilitering van die pastoraat aan my gespreksgenote, veral wat betref die verdiskontering van die impak van misbruik op verhoudings in die wydste moontlik sin (Killian \& Brakarsh 2004:371-372, Spies 2006:241).

Uit die ingeslote fragmente en komende van die verhale van my gespreksgenote is duidelik aangetoon op watter wyse hulle selfwaardering in die lig van hoe hulle God verstaan het, aanvanklike skeefgetrek was en tot die vernietiging van hoop gelei het. Daar is egter ook aangetoon dat - soos wat 'n hoopvolle toekoms saam met hulle uit die verlede gekarteer word - 'n nuwe werklikheid aangebreek het met as inhoud die Christelike hoop ${ }^{8}$ “... qualified by the cross and the resurrection of Christ" (Louw 2008:238).

\section{BIBLIOGRAFIE}

Anderson, RS 2001. The shape of practical theology. Empowering ministry with theological praxis. InterVarsity Press: Downers Grove.

Clinebell, HJ 1966. Basic types of pastoral care and counseling: Resources for the ministry of healing and growth. Abingdon Press: Nashville.

Crisp, BR 2007. Spirituality and Sexual Abuse: Issues and dilemmas for survivors. In Theology and Sexuality. 13(3):301-314. Retrieved from the World Wide Web on 31January 2010 at http://www.soul-expressions-abuse-recovery.com

De Beer, A \& Van den Berg, JA 2011. A discourse on eschatology and promissiotherapy with women after the loss of a husband. In die Skriflig. 45(1):141-159.

Delport, CSL \& Fouché, CB 1998. The Place of theory and the literature review in the qualitative approach to research. In Research at grassroots level. A primer for the caring professionals. Third edition. Edited by AS de Vos; HY Strydom; CB Fouché \& CSL Delport. Van Schaik: Pretoria. 261-266.

Dobson, J 1999. Spesiaal vir tieners. Hoe om fisieke en emosionele veranderings in jou tienerjare te oorleef. Christelike Uitgewers Maatskappy: Vereeniging. Vertaal in Afrikaans in 2007.

Duval, J \& Béres, L 2007. Movement of identities. A map for therapeutic conversations about trauma. In Narrative therapy. Making meaning, making lives. Edited by C Brown \& T Augusta-Scott. Sage Publications: California. 229-250.

Ganzevoort, RR 2001. Religion in rewriting the story: Case study of a sexually abused man. The International Journal of Psychology of Religion. 11(1):45-62.

Ganzevoort, RR 2007. Waarheen met de praktiesche theologie? Theologische Debat. 4(1):20-24.

Ganzevoort, R \& Visser, J 2007. Zorg voor het verhaal. Actergrond, methode en inhoud van pastorale begeleiding. Uitgeverij Meinema: Zoetermeer.

Ganzevoort, R 2008. Scars and stigmata: Trauma, identity and theology. Practical Theology. 1(1):19-31.

8 "Christian hope deals with the unseen dimension of true life and must be interpreted as an eschatological event” (Louw 2008:238). 
Gerkin, CV 1986. Widening the horizons. Pastoral responses to a fragmented society. The Westminster Press: Philadelphia.

Gower, G; Dowling, E \& Gersch, I 2005. Parenting adult children. A project combining narrative, clinical and empirical methodologies. In Narrative therapies with children and their families. A practitioner's guide to concepts and approaches. Edited by A Vetere \& E Dowling. Routledge: London and New York. 85-100.

Guma, M \& Henda, N 2004. The social-cultural context of child abuse: A betrayal of trust. In Sexual abuse of young children in South Africa. Edited by L Richter; A Dawes \& C Higson-Smith. HSRC Press: Cape Town. 95-109.

Heaven, PCL 2001. The social psychology of adolescence. Palgrave Publishers: Hampshire.

Heitink, G 1979. Pastoraat als hulpverlening. Inleiding in de pastorale theologie en psychologie. Tweede druk. Uitgeversmaatschappij JH Kok: Kampen.

Louw, DJ 1999. Pastoraat as vertolking en ontmoeting. Teologiese ontwerp vir 'n basisteorie, antropologie en terapie. US Drukkery: Stellenbosch.

Louw, DJ 2007. Hoe teologies is die praktiese teologie en hoe prakties is die teologie? Ontwerp vir 'n prakties-teologiese hermeneutiek. Praktiese Teologie in Suid-Afrika. 12(2):43-63.

Louw, DJ 2008. Cura Vita. Illness and the healing of life. Wellington: Lux Verbi. BM.

McGregor, K 2008. Surviving and moving on. Self-help for survivors of childhood sexual abuse. Random House: New Zealand.

Moore, JG 1985. The ABC of Child abuse work. Gower Publishing Company Limited: Aldershot.

Müller, J 1996. Om tot verhaal te kom. Pastorale Gesinsterapie. RGN-studies in die Praktiese Teologie. Die RGN Uitgewery: Pretoria.

Müller, JJ 2010. 'n Refleksie op menswees aan die begin van die 21ste eeu. Retrieved from the World Wide Web on 2 September 2010 at http://www.gotquestions.org/practical-theology.html

Müller, J, Van Deventer, W \& Human, L 2001. Fiction writing as metaphor for research: A narrative approach. Praktiese Teologie in Suid-Afrika. 1692:1-13.

$\mathrm{Nel}, \mathrm{M}$ 2000. Youth ministry. An inclusive congregational approach. Vertaal deur E de Waal. Design Books: Clubview.

Olson, G 2006. Teenage Girls. Exploring issues adolescent girls face and strategies to help them. Zondervan: Grand Rapids, Michigan.

Osmer, RR 2008. Practical theology. An introduction. William B Eerdmans Publishing Company: Cambridge, UK.

Perrin, DB 2005. Mysticism. In The Blackwell companion to Christian spirituality. Edited by A Holder. Blackwell Publishing: Malden, Oxford, Victoria. 442-458.

Richardson, S \& Bacon, H 2001. Creative responces to child sexual abuse. Challenges and dilemmas. Revised edition (2003). Jessica Kingsley Publishers: London.

Shotter, J 1993. Conversational realities. Constructing life through language. Sage Publications: New Delhi.

Schmutzer, AJ 2008. A theology of sexual abuse: A reflection on creation and devastation. JETS. 51(4):785-182. 
http://scriptura.journals.ac.za

'n Narratief-pastorale betrokkenheid by adolessente meisies wat seksueel misbruik is

Snodgrass. KR 2011. Introduction to a hermeneutics of identity. Bibliotheca Sacra. January - March 2011:3-19.

Spies, GM 2006. Sexual abuse. Dynamics, assessment \& healing. Van Schaik Publishers: Pretoria.

Swinton, J \& Mowat, H 2006. Practical theology and qualitative research. SCM Press: London.

Van Aarde, A 2004. Skrifbeskouing in die lig van postmoderniteit. Hervormde Teologiese Studies. 60(1\&2):1105-1119.

Van den Berg, JA 2006. 'n Verandering in tongval ...? 'n Verwoord(beeld)-ing van pastoraal teologiese perspektiewe. Praktiese Teologie in Suid-Afrika. 2:164-181.

Van Huyssteen, JW 1998. Duet or duel? Theology and science in a postmodern world. Trinity Press International: Pennsyvania.

Van Niekerk, AA 2005. Geloof sonder sekerhede. Besinning vir eietydse gelowiges. Lux Verbi BM: Wellington.

White, M 1992. Deconstruction \& therapy. In Experiences, contradiction, narrative \& imagination: Selected papers of David Epston \& Michael White. Dulwich Centre Publications: South Australia.

Waaijman, K 2002. Spirituality. Forms, foundations, methods. Peeters: Leuven.

Wickham, RE \& West, J 2002. Therapeutic work with sexually abused children. SAGE Publications Ltd: London.

Williams, RR 2010. Space for God: Lived religion at work, home and play. Sociology of Religion. 71(3):257-279. 